\title{
Korean Men in Western film festival: The representation of filmic masculinity in five South Korean award - winning films
}

\author{
Gabriel. F. Y. Tsang
}

\begin{abstract}
Masculinity is volatile, subject to representation. It is both personal and collective, interchanging with historical and cultural dynamics. This essay holds a focus on Korean masculinities represented in five award-winning South Korean films. In both diachronic and international perspectives, it differentiates between ideal, real and filmic masculinities, illuminating that ancient and modern Korean masculinities do not purely stick to a fixed, expected and shared ideology. There are variations in response to personal intention, nationhood and cultural globalization. The main argument of this essay is that conventional regulation is not the sole source to influence masculinity representation. Even violation of idealized manhood could deliver a sense of masculinity. Extending this argument to the concern with international film marketing, this essay questions about whether diversification of gender features would blur Korean masculinity and create new gender identification.
\end{abstract}

Keywords - cultural globalization, masculinity, nationhood, South Korean films

\section{INTRODUCTION}

A fter the commercial success of Kang Jegyu's Shiri (1999), attracting 5.8 million viewers that beat the local box office record set by Titanic (4.7 million viewers) (Kim Youna 2013, $10)$, the South Korean film industry revived. It welcomed a prolific new wave, encouraging mass production of films with higher quality that supported a marketing war against Hollywood products internally and overseas, and delivering a sense of internationalization. Unlike the French New Wave, lasting from the late 1950 s to the $1960 \mathrm{~s}$, that focused on personalizing the themes and techniques of films, Korean New Wave, despite innovative ways of expression, is more

Received: 10-01-2018, Accepted: 11-5-2018; Published: 30-9-2018

Gabriel F. Y. Tsang, Sun Yat-sen University

Email: tsangfanyu@hotmail.com social. It has a stronger sensitivity to the national identity and cultural specificity of South Korea. It replicates some filmic elements from other regions, such as actions from Hong Kong, documentary styles from China and explosive scenes from the United States, but simultaneously remains its focus on rendering Korean-ness. The emphasis of Korean-ness is a crucial way for South Korean films to differentiate themselves from their competitors, and to let film critics, especially the Western ones, make clear identification.

2002 and 2004 are two significant years in the Korean film history. They mark the critical success of South Korean films. In 2002, Im Kwon-taek won the Best Director Award for Chihwa-seon (also known as Painted Fire, Strokes of Fire or Drunk on Women and Poetry) at the Cannes Film Festival, whereas Lee Chang-dong's film Oasis won the Special Director's Award, the Fipresci Best Film Award, the Signis Award and the Marcello Mastroianni Award at the Venice Film Festival. In 2004, Park Chan-wook's Oldboy won Grand Prix at the Cannes Film Festival, and Kim Ki-duk won the Best Director Award for Samaritan Girl and four awards for 3-Iron (including the Best Director Award, the Fipresci Best Film Award, the Little Golden Lion Award and the Signis Award) at the Berlin Film Festival and the Venice Film Festival respectively. The success of five Korean films in two years at three major art film festivals does not simply mean separate acceptance of individual efforts paid to renovate Korean genres. It implies a critical notice of the rise of collectively constituted filmic formula that represented the self-identification of South Korean nationals.

Four Korean directors mentioned above are all men. Including Kim Ki-duk's Samaritan Girl, which is about the female protagonist offering free prostitution after the death of her best friend, those award-winning films have male characters 
playing significant roles. The themes of the films are basically androcentric. Directors generally assign actors to certain roles according to the function and characterization that match their physical sex, with a principle that women are under control and suppressed. In the following sections, I will address the masculine issues through studying and contextualizing the volatile masculinity represented in the five films.

\section{IM KWON-TAEK'S CHI-HWA-SEON: IMAGINING ANCIENT KOREAN MASCULINITY}

As the first Korean film that won a major award from one of the three most important art film festivals, Chi-hwa-seon is a delicate pastiche of the cultural elements of the nineteenth-century Korea. Like Japanese director Akira Kurosawa's Rashomon (1950), which won Golden Lion Award at the 1951 Venice Film Festival, and Chinese director Chen Kaige's Farewell My Concubine (1993), which won Palme d'Or at the 1993 Cannes Film Festival, this film brought the national film industry into the gaze of judges and satisfied their expected Oriental imagination. Kate E. Taylor-Jones quoted Kim So-young's statement that Chi-hwa-seon "provides a framework through which the present South Korean problems under the globalization era can be rethought" and referred it to "the perceived desire of $\mathrm{Im}$ to appeal to the international audience rather than focusing on the domestic one" (2013: 49). That means the ancient setting of this film creates an aesthetic illusion that alienates both local and overseas audience from their familiar contemporary contexts. However, the cultural elements that modern South Korea has inherited from the past shortens the cognitive distance between the daily perception of the South Korean audience and the narrated past of the film. In contrast, for the Western audience, the integration of various artistic elements, such as traditional painting with ink and brushes, playing Dizi (a traditional Chinese instrument) and tea ceremony, largely detach them from their everyday experience and identification of Korean specificity.

Masculinity, like cultural and artistic elements, can create an effect of defamiliarization. ${ }^{1}$ It is

\footnotetext{
${ }^{1}$ According to Viktor Shklovsky who conceptualized the term "defamiliarization," "The purpose of art is to impart the sensation of things as they are perceived and not as they are
}

cognitive, perceivable and ever-changing. Filmic masculinity makes a reference to the masculine representation in reality, and can imitate, distort, exaggerate, extract and modify it as what a director consciously or unconsciously intends. Merely applying textual analysis, one can merely identify masculinity through differentiating it from the elements that female characters represent. In Chi-hwa-seon, Jang Seung-eop has clear personalities opposite to those of female characters. In the love relationships, except the first one that he fails because of his inferior social identity, he usually plays an active role to make choices, instead of being chosen. The women he met, except a prostitute, are all incapable of sustaining their lives through laboring and hence need to depend on their fathers, husbands or male sex partners. The low education level and social status cause their compliance with the men's commands, as what Mary Wollstonecraft (1792) criticized and reasoned about the subordinated condition of European women in her era. For instance, the sister of Jang Seung-eop's master follows her brother's arrangement to get married with a man whom she may not love but can give her economic support. Besides, the sex partner of Jang, who truly loves him, needs a sexual relationship with another painter in order to survive, after Jang left her for a long time for drawing in the countryside. Under the observable social structure in the film, one can conclude that the Korean masculinity represented in Chi-hwaseon comprises rather arbitrary behaviors, dominant social position and freedom of disobedience. This kind of masculinity is also observable in other ancient Korean films, such as Hwang Jin Yi (2007) concerning a roguish male family servant becoming the instructor of a legendary prostitute who had been his mistress.

Christina K. Gilmartin asserts that "Gender is relational; femininity and masculinity make sense only in relation to each other, and behaviours that are thought to transgress gender boundaries can be understood only if we know how a particular society has mapped those boundaries." (1994: 1). She points out ther elativist nature of gender characterization and identification, especially the importance of society in assigning masculinity to

known. The technique of art is to make objects 'unfamiliar,' to make forms difficult to increase the difficulty and length of perception because the process of perception is an aesthetic end in itself and must be prolonged." (1998: 16). 
men and femininity to women, and setting boundaries between two genders through the assignment. The binary opposition involves a sophisticated process of signification. In Moira Gatens's view, this process is a historically and culturally given fact. She suggests that masculinity and femininity, as imaginary products, have no "fixed essence," but rather a "historical specificity" (1996:11,16). History differentiates bodies and withdraws the inbetweenness of genders. That is why Gatens, with a practical concern, asserts that "there is no neutral body, there are two kinds of bodies: the male body and the female body" (1996:8). Provided that all human beings have biological sex and this sex has been granted two sets of meanings, a progressive way to continue our discussion is to focus on what Korean masculinity exactly is in the social context of the films and to what extent the men in films represent Korean masculinity.

Juxtaposing the filmic world and the real world, one can simply say that Chi-hwa-seon is a story about pre-modern Korea, created in modern Korea. What Im Kwon-taek had to consider during the filmmaking process is how to represent the great ancient male painter Jang Seung-eop. Regardless of whether targeting on winning Western awards through shaping a typical Korean male figure, Im had to consider Korean male elements in order to transcend his understanding about present Korean men, which he could observe in the everyday life. Historically, Koreain the Joseon Dynasty (1392 to 1897 A.D.), while Jang Seung-eop stayed for his whole life time (from 1843 to 1897), was deeply influenced by the Han culture, which is the culture of its only continentally adjacent nation - China. Like premodern Japan, Korea largely imitated, internalized and localized the cultural, political and social elements of China, in order tosupport its civilization. Confucianism dominated various important areas of thoughts since the Goryeo Dynasty (918 to 1392 A.D.). Its focus on the concept of Junzi - the morally ideal man-not only shadows the social function of women and centralizes the position of men in the power hierarchy constituted according to social identity and family responsibility, but also restricts the behaviors of men with specific guidelines. To achieve required moral standards, a Confucian man has to comply with a series of etiquette (li) and be righteous (yi). In Chi-hwa-seon, Jang Seung-eop has some performances unrelated to masculinity in the Western gaze, such as his consistent respect for his teacher. He keeps this respect even after his teacher acknowledges that the artistic achievement of Jang is higher than his. In the Confucian sense, what Jang does related to his teacher, such as feeling shameful after occupying an important space in the paper for a painting contributing to an important officer, shows his compliance with the ethical discipline in which identity is more determinative than ability. Despite concerning debauchery more than a family life, Jang Seung-eop is overall perceived as an adorable figure, at least within the gaze of East Asian audience. It is not because of Jang's drawing talent, but, as the director expresses, because of his persistent pursuit for artistic advancement and his unconscious concern of the national plight. His mentality achieves a high level of moral standard traditionally imposed on men - prioritizing the security of homeland and personal spiritual achievement, rather than the internal harmony of family that is regarded as subordinate. In a still patriarchal society, despite the fading influence of Confucianism, the performance of Jang Seung-eop actualizes the central and classical moral belief in the past, in response to the variation of manhood in the globalizing present. It successfully satisfied the moral need of the Korean audience, who collectively sustain the historical inertia of traditional values and androcentrism, in the age while rapid growth of local cultural industry has been unstablizing and blurring their gender roles, personal identity and social position. Meanwhile, the personality of Jang, different from those Western male characters perform, allows international critics to figure out specific ideology of Korea, not as replication of other national ideologies, for theorization, classification and canonization. It draws both local and international attention to national specificity founded on historical features. Furthermore, the artistic recreation of a past male figure has allegorical function to represent a nation. The masculinity of Jang is not merely a contrast to femininity, but also a practice of additional moral duties that guarantee national stability and prosperity. This practice corresponds to the ambitious development of South Korea in recent decades. 


\section{MALE HOOLIGANS ON THE SCREEN: THE IDEAL, REAL AND ARTISTIC REALMS OF MASCULINITY}

In the case discussed above, there is ambiguity between Korean masculinity and Chinese masculinity, because Korea and China had shared the same set of moral ideology for over a thousand years. Due to the deep influence from the Chinese culture of the Tang Dynasty, while Confucianism was dominant in the Chinese academia, modern Japanese men similarly inherit some canonized male elements, which Japanese directors can transform into the idealized components of male characters in their narratives. Theso-called "East Asian Cultural Sphere," consisted of China, Japan, Korea, and Vietnam, ${ }^{2}$ shapes and reproduces Oriental imagination through configuring fictive characters or re-creating real historical figures that match relevant contexts.

It is important to not just focus on the ideal side of masculinity. Song Geng and Derek Hird raised a significant point in the introduction of their coedited collection of essays on Chinese masculinity. They questioned whether Chinese have masculinity because Chinese men generally fail to practice it as what cultural tradition requires (2014:1-2). Their question is based on a concern that masculinity is an idealized product of collective imagination. It can be represented through artworks rather than everyday life. To avoid minimizing masculinity to the extent that one can claim there is no summarize able difference between men and women in reality, dividing masculinity into ideal masculinity and real masculinity is crucial. Real masculinity is more complicated than the ideal one, as it is hybrid representation of the implementation or violation of moral doctrines, social expectation, cultural fashion and personal habits.

In the case of the five Korean films I selected, it is apparent that Korean directors did not totally comply with the Confucian ideal. For instance, Jang Seung-eop, as what I discussed before, the character that fulfills Confucian requirements at a high level, is not a role model of Korean men to a certain extent. He is self-indulgent and has never built up a nuclear family with his lovers. He is not a junzi (an ideal male figure that Confucianism

\footnotetext{
${ }^{2}$ The Sinologist John Fairbank indicated that the Confucianism and Han text of ancient China are the core of the East Asian culture, influencing Vietnam, Korea and Japan.
}

suggests) that can moderate everything properly and can keep good relationship with different kinds of people. However, it does not mean that he is partially masculine. He is just a partially ideal man instead. His shortcomings compose part of his masculinity, in contrast to the femininity that Im Kwon-taek composed for female characters in the same film. Comparatively, Lee Chang-dong's Oasis and Park Chan-wook's Oldboy, set in the modern Korean society, shows far less attemptsto moralize male characters in a traditional manner. Hong Jong-du in Oasis and Oh Dae-suin Oldboy are both hooligan-like characters. Hong Jong-du usually rubs his nose and is usually unable to control himself and follow social rules. $\mathrm{He}$ is different from the cerebral-palsy-stricken female protagonist Han Gong-ju, who keeps her place clean and wears properly despite disability. $\mathrm{He}$ is also different from his brothers who can hypocritically play their social role well in the everyday life (except the fact that the older brother is the culprit of a hit-and-run that causes Hong Jong-du, who agrees to be a scapegoat, to be imprisoned, and two brothers keep discriminating Hong after his release). In terms of real masculinity, the difference between him and others does not mean that his behaviors belong to a third gender or Hong Jong-du is less masculine than his brothers. Instead, Hong performs his masculinity in a specific category that is out of the scope of traditional morality. Likewise, Oh Dae-su in Oldboy is not an ideally righteous male character. He just aims to take revenge to the one who kidnapped and then imprisoned him for 15 years without a reason. National issues are absent in Park's narrative, unlike Im Kwon-taek's Chi-hwaseon which usually highlights the diplomatic plight of feudalist Korea. Due to filmic designs, Oh Dae-su is a character out of the social and political context of contemporary Korea. He has no responsibility to contribute to his nation in any way. However, he feels obliged to follow ethic discipline and is, hence, extremely regretted after knowing that he accidently had sex with his daughter. According to Confucianism, father has to play the role as a leader of his nuclear family, but Oh Dae-su fails to maintain this internal discipline. He is even, ironically, the law-breaker. The director takes advantage of the unethical relationship to create conflicts surrounding the villain who is the ultimate avenger, but not to 
foreground the protagonist's failure to comply with the traditional value. The free will of male characters reduces the sense of responsibility of subjecting themselves to collective harmony. They perform their manhood through violating or ignoring the moral routines, instead of obeying them. In both films, hooligan protagonists are not up to the Confucian standard, revealing more real and complete personalities that contain both righteousness and evilness. They are basically individualistic and anti-social, and are realistic rather than idealistic. The directors constitute their masculine specificity through narrating, and sometimes repeating, their eccentric behaviors.

The process of designing the actions of actors is also a process of creating internal gender ideology of a film. Here, gender ideology refers to, as Linda Martín Alcoff defines, "set of practises which organizes, regulates and defines relations between men and women" (1996:20). It "works to produce gender, or masculinity and femininity" (1996:20). In Oasis, Hong Jong-du gets a job as a delivery boy for a Chinese restaurant after his release from prison, but loses it promptly, because his curiosity about filmmaking on the road makes him crash a motorcycle that belongs to the restaurant. He visits Han Gong-ju, the handicapped daughter of a man who died because of an accident that his elder brother caused. At the second time he meets her, at her home while there is no one else, he attempts to rape her. After she faints because of shock, he gives up. Later on, Han Gong-ju calls him by phone because of the mistreat from her brother and her neighbor that increases her solitude. Then, two misfits build up a love relationship. Hong Jong-du does not get rid of his mental weirdness while loving a wellbehaved girl. He steals his sister-in-law's money in order to date Han Gong-ju, and he deliberately annoys the customers of a restaurant because its owner does not want them to eat inside because of Han's physical weirdness. Hong even takes Han to his mother's birthday banquet without noticing, and hence embarrasses all his family members. As Han wants to be a real woman and really loves Hong, she asks for making love with him. He does, but is finally discovered by Han's brother and sister-in-law. Han is unable to speak for proving Hong's innocence because of shock, and Hong cannot defend for himself, especially because of his previous criminal records. What Hong can do is just to escape from the police station while a pastor is praying for him. At the end of the story, he runs to a tree in front of Han's apartment and cuts its branches whose shadow scares Han at night. Overall, his arbitrary behaviors and particular care to a girl who is socially discriminated composes his specific masculinity. It is different from the femininity that female characters in the film perform. Hong's sister-in-law, Han's neighbor and her sister-inlaw, as physically sound and hence normal women, are all sensitive to shame. They are rather silent, usually letting men speak first and speak on behalf of them. They are basically kind and polite to the people both inside and outside their family, regardless that they may behave reluctantly and hypocritically. Unlike men who can act radically, like Hong's brother who can shout at Hong and hit him with an iron pipe as punishment after he found that Hong secretly drove a customer's car for a date with Han, women just usually give comments and help mediating interpersonal tensions. For example, after Hong went back home after arrested by policemen for not paying for a meal, his sister-in-law urges him to wash his feet with a puckish tone. After he broke the motorbike of the restaurant he worked for, she carefully washes his wound and calmly tells him,

I am sorry to tell you this, but I really don't like you. I know this sounds harsh, but with you out of the way, I felt good about life. Without you, we had no worries. It's not only me, but your brother and your mum feel the same way. I didn't want to tell you, but it has to be come out.

The sister-in-law patiently maintains the discipline of her family with tenderness. Although she is unwilling to serve her brother-in-law, she does so in order to fulfil her social role as the wife of the elder son of a family. Her calmness and honesty generate a soft power that can admonish him without physical conflicts. It is quite clear that the women in the film are usually behind men. They handle daily difficulties with opposite approaches.

Gender difference is similarly clear in Oldboy. Under a setting that men occupy most of the scenes and plots, women mainly function as objects of men's love. Their performance, using Chuyun Oh's words, "delivers the patriarchal image of fragile, submissive and passive femininity" $(2014: 58)^{3}$. In contrast, male

\footnotetext{
${ }^{3}$ The quotation is originally from Chuyun Oh's description about a South Korean girl group, called "Girls' Generation."
} 
characters are usually violent, self-indulgent and aggressive. At the beginning of the film, male protagonist Oh Dae-su is arrested because of drunkenness. A secret man Lee Woo-jintraps him into a room for 15 years, during which Oh Dae-su does a lot of boxing training as a preparation for his avenging plan. He becomes more powerful, muscular, and ready for fights. The process transforms his masculine representation from being debauched into being self-disciplined and pugnacious. No matter before or after the imprisonment, the audience can spontaneously identify him simply as a man, but not a feminine man or a man without masculinity. The latter image of Oh Dae-su is generally more preferred for the audience, because his physical and mental quality favors a control of situation, implying the potential to practice righteousness as what the audience would expect according to his gender identity. In Theorising Chinese Masculinity: Society and Gender in China, Kam Louie argues that there are two kinds of masculine elements in the context of ancient China: wen (cultural attainment) and $w u$ (martial valor). Through analyzing the representation of masculinity in Chinese artworks, he summarizes that Chinese masculinity includes not only "physical strength and military prowess," but also "refined qualities that were associated with literary and artistic pursuits of the classical scholars" (2002:9). Regardless of whether this division is totally applicable for analyzing the filmic representation of modern South Korea, it at least provides convenience for us to know why we perceive an fictive image as masculine or not. There is a cultural genealogy that historically accumulates knowledge and perception of two genders and lead to the occurrence of collective unconsciousness about gender identification. Jang Seung-eop in Chi-hwa-seon is certainly an example of a man representing "cultural attainment."

One has to notice that Jang inherits the more important and superior side of masculinity. As Korean imported the ideology of "honoring the civil while suppressing the military" (zhong wen qing $w u$ ) from China prevailing since Song

See Chuyun Oh, "The Politics of the Dancing Body: Racialized and Gendered Femininity in Korean Pop," in The Korean Wave: Korean Popular Culture in Global Context, ed. Yasue Kuwahara (New York: Palgrave Macmillan, 2014), 58.
Dynasty (960 to 1279 A.D.) (Pierre Marsone and John Lagerwey 2014:1379), they long regarded intellectuals as superior to warriors. Intelligence was a symbol of civilization and the core part of bureaucratic system that determined the national prosperity and diplomatic direction of Korea.

However, the artistic asymmetry between two sides of masculinity has been turned around in the South Korean award-winning films. The development of violent aesthetics grants martial masculinity discursive power, overwhelming intellectual masculinity, although the real situation can be different (like the situation that getting into the best universities, rather than serving the military force, is more socially preferred). In Oldboy, there are many fighting scenes that show the male protagonist's rudeness and unthoughtfulness. However, he is accepted by the audience because their previous film-watching experience has validated their expectation on avenging through repetitive fist-fighting. Due to the globalization of film industry, fighting, as one of the most important filmic elements that grants the audience visual excitement, has been a reasonable way for narrated men, especially East Asian men, to achieve certain goals, such as taking revenge, testing personal abilities, defeating villains and so on, in afictive world. The pursuit of visual effects and the narrative validation of cruel behaviors appropriated a kind of masculinity that is less respected in reality. Such masculinity, reflecting male desires to instantly fight for a result rather than using intelligence to solve a problem, corresponds to Sigmund Freud's first instinctual drive theory. According to Henri Parens's interpretation, the innate death-instinct-based aggressive drive is self-destructive but can "turn outward from the self onto objects." (2008:41). That means violence is the most autonomous response of human beings to threats, and intelligence is only a secondary drive. However, under social construction of morality, the secondary drive has become more ideal and universally accepted. Paradoxically, Oldboy, like many local and overseas action films, recalls the aspiration of first-drive problemsolving of the public. This aspiration has sex discrimination, seeming to consolidate a stereotypical understanding of men as the most original and first-sex beings. 


\section{KOREAN MANWITHOUT KOREAN- NESS AND GENDER STABILITY IN THE GLOBALIZING WORLD}

In Korean Masculinities and Transcultural Consumption, Sun Jung stresses that "contemporary South Korean popular culture travels across national and cultural borders" (2011:3). It is "hybridized and influenced by various foreign cultures through transcultural flows largely facilitated by advanced media technology and globalization" (2011:3). He identifies the principal trait of South Korean creative industry, in accordance with what Koichi Iwabuchi terms the "cultural odorlessness" of Japanese consumer products, as mugukjeok (nonnationality), which "enables South Korean popular culture to be globally consumed" (Sun Jung 2011, 3). In order to raise income or earn reputation from the international market, South Korean films, on the one hand, typify some key Korean features and, on the other hand, replace its locality with various foreign filmic elements. Two sides both result in externalization of national features that may weaken the reflection of the South Korean everyday life. The externalization can penetrate the everyday life of Korean individuals, regulating their perspective about gender and reducing their sensitivity to consolidating nationally specific masculinity or femininity. It habitualizes their taste and preference of consumption, within certain sorts of gender fixation that are rather universally and globally typical.

In Kim Ki-duk's Samaritan Girl, the female protagonist Jae-yeong is at the central position of the narrative, whereas male characters play assistant roles. The story is mainly about a teenage girl Jae-yeong, who prostitutes herself and returns money to those who had sex with her friend Yeo-jin, after Yeo-jin died because she jumped out of a window in avoidance of getting arrested by the police. Jae-yeong had asked the man whom Yeo-jin loves to see Yeo-jin before she died, but he agreed to do so only if Jae-yeong had sex with him. After Jae-yeong did, they arrive at hospital and finally see that Yeo-jin dies with a smiling face. Jae-yeong then starts to use the abnormal way to inform Jae-yeong's clients of her death in order to let them feel guilty and, at the same time, redeem her personal sin. After Jaeyeong's father discovered what Jae-yeong is doing, heuses increasingly brutal ways to punish the men who have had sex with his daughter. The gender contrast in this film is very obvious as in the films that I discussed above. Woman body is the sexual object for men to abuse, repress and consume (except the case that Jae-yeong's father protects his daughter's body because of his family identity). This structure is similar to that of The Crucible (2011), in which men can be harmful pedophiles and rescuers, and the female characters can only be victims and help-seekers. The owner of a biologically female body can only resist patriarchal oppression through first complying with it. A specific point about masculinity in this film is that male characters nearly have no moral function. They do not, or fail to, act as saviors. Most of them abuse the bodies of Yeo-jin and Jaeyeong, some among them feel shameful and even commit suicide. Although Jae-yeong's father is righteous in the aspect of sexuality, he cannot even save himself after killing a man for vengeance. The physically powerful, but mentally cunning, selfish and fragile male images overturn the validity and achievability of ideal masculinity. The narration of the male characters universalizes the oppressive nature of men, which actively and unfairly harms women, and their cowardice about resolving the plights that they individually or collectively cause. An important point is that universalization is a process of typifization, leading to a loss of specificity. The typifization of men in Samaritan Girl, as sexually obsessive and thoughtless, to a certain extent, empties out their nationality and hence lets them be general men, instead of Korean men, that advantage global consumption. Their understandable performance, obeying the global cultural logic, let this film more easily reach the standard of humanitarian that international critics set, regardless of the regional interpretation of the same concept.

In another award-winning film3-Iron, Kim Kiduk further empties out Korean manhood, for enabling a reflection on gender relationship in the contemporary world. Throughout the film, the male protagonist Tae-suk does not show clear gender features. Except the preference for watching pornographic images, he acts either like a woman or genderless. In the story, he usually pastes flyers on a lot residential gates, and then sneaks into one of the empty houses. He never steals anything, but lives in the houses as if they are his home. He cooks for himself, takes selfies with the decoration of the flats, and helps the flat 
owners to wash their clothes and to repair broken items. He is an absolutely silent character, even after he met the female protagonist Sun-hwa when he broke into her house. Sun-hwa is a typical woman, matching the traditional female image that the audience expects. She is introvert and is a victim of domestic violence. Her husband is a clearly vicious and selfish man, like those Kim Ki-duk shaped in Samaritan Girl. He is very possessive of his wife and highly desires to take revenge on Tae-suk after he attacked him with golf balls. In contrast, Tae-suk does not resist any kinds of attack, like Sun-hwa, and never fights with his fists. He does not have strong eagerness to possess the body of Sun-hwa, even after Sunhwa escapes from her home and follows him. For most of the time, Tae-suk and Sun-hwa does the same things at the homes of strangers. They share the housework that is traditionally assigned to women, and both disregard their identity in unfamiliar space, in order to seek for a lifestyle that is conflict-free. The absence of speech of two protagonists and the abnormal behaviors of Taesuk not only give out a suggestion about how to minimize interpersonal disputes, but also dissolve gender stereotypes and create a new masculine possibility. At the end of the story, after Tae-suk was imprisoned because of his suspicious actions, including kidnapping Sun-hwa and burying someone's father, he obtains an ability of hiding behind people without being noticed. He becomes a transparent figure who can keep his love relationship with Sun-hwa, even though her husband is present. The absurdity that the director creates reveals the variability and flexibility of masculinity in the realm of virtuality. Filmic masculinity does not need to follow real masculinity. It follows the intention of director, the reception of the audience and the dynamic of the global culture instead. The critical success of 3-Iron implies that the international audience welcomes the production of non-national male images. In this case, they prefer unfamiliarity to locality. Such preference leads to a possible assumption that the global presentation of gender in films will become increasingly ambiguous and unstable. As we can see in the recent history of South Korean cinema, female characters take more active roles in the stories. Menno longer represent righteousness and act as the stabilizer of interpersonal relationship. It is foreseeable that, as South Korean films is becoming more globalized, or at least aiming to be so, directors will formulate more kinds of masculinity for international consumption. Korean male characters may be feminine, gay or queer, according to the favors of the audience.

\section{CONCLUSIONS}

In this essay, I examine the masculinity represented in five award-winning South Korean films, through which I differentiate between ideal, real and filmic masculinities and apply them to analyze the dynamic relationship between nationhood and manhood. Im Kwon-taek's Chihwa-seon shows how an ancient Korean male painter actualizes high ethic values that Confucianism, to which Korea long attaches its central ideology, traditionally assigns to men. In contrast, two different kinds of hooligan in Lee Chang-dong's Oasis and Park Chan-wook's Oldboy - one is shameless and one is aggressive, respectively - are rather realistic and do not follow historically-inherited ideal features. They lay on the fashion of the East Asian cultural industry and entertain the audience who have been fed up with the stories about good men and their ideal lives. Kim Ki-duk's two works (Samaritan Girl and 3-Iron) made even less reference to traditional masculinity. Their male characters are villains or losers, whose performance is for addressing universal and private issues, such as the lust of man, rather than local social issues. The male protagonist of 3-Iron is special, as the audience can hardly identify both his Korean-ness and masculinity. He is like a mark of cultural globalization, which had rapidly blurred local specificities for global consumption. Such globalization not only brought the South Korean director critical success in art film festivals due to his innovative formulation of a non-national man, but also implies the increasing instability of being men in Korea.

\section{REFERENCES}

[1]. 3-Iron. Directed by Kim Ki-duk. 2004. London: Studiocanel, 2005. DVD.

[2]. Alcoff, Linda Martín. 1996. "Feminist Theory and Social Science: New Knowledge, New Epistemologies." In Body Space: Destablizing Geographies of Gender and Sexuality, ed. by Nancy Duncan,13-27. London: Routledge.

[3]. Chi-hwa-seon. Directed by Im Kwon-taek. 2002. New York: Kino on Video, 2004. DVD.

[4]. Farewell My Concubine. Directed by Chen Kaige. 1993. London: Bfi, 2016. DVD. 
[5]. Gatens, Moira. 1996. Imaginary Bodies: Ethics, Power and Corporeality. London: Routledge.

[6]. Gilmartin, Christina K., et al. 1994. "Introduction." In Engendering China: Women, Culture, and the State, ed. by Christina K. Gilmartin et al.,1-26. Cambridge. Massachusetts: Harvard University Press.

[7]. Hwang Jin Yi, Directed by Jang Yun Hyeon. 2007. Seoul: CJ Entertainment, 2012. DVD.

[8]. Kam, Louie. 2002. Theorising Chinese Masculinity: Society and Gender in China. Cambridge: Cambridge University Press.

[9]. Kim, Youna. 2013. "Introduction: Korean Media in a Digital Cosmopolitan World." In The Korean Wave: Koren Media Go Global, ed. by Youna Kim.1-28. Routledge: New York.

[10]. Marsone, Pierre and John Lagerwey, ed. 2014. Modern Chinese Religion I (2 vol. set): Song-Liao-Jin-Yuan (960-1368 AD). Leiden: Brill.

[11]. Oasis. Directed by Lee Chang-dong. 2002. London: Third Window films, 2009. DVD.

[12]. Oh, Chuyun. 2014. "The Politics of the Dancing Body: Racialized and Gendered Femininity in Korean Pop." In The Korean Wave: Korean Popular Culture in Global Context, ed. by Yasue Kuwahara, 53-83. New York: Palgrave Macmillan.
[13]. Oldboy. Directed by Park Chan-wook. 2004. New York: Tartan, 2005. DVD.

[14]. Parens, Henri. 2008. The Development of Aggression in Early Childhood. Lanham: Jason Aronson.

[15]. Rashomon. Directed by Akira Kurosawa. 1950. London: Bfi, 2015. DVD.

[16]. Samaritan Girl. Directed by Kim Ki-duk. 2004. New York: Tartan, 2006. DVD.

[17]. Shklovskij, Viktor. 1998. “Art as Technique." In Literary Theory: An Anthology, ed. by Julie Rivkin and Michael Ryan. Malden: Blackwell Publishing Ltd.

[18]. Sun, Jung. 2011. Korean Masculinities and Transcultural Consumption: Yonsama, Rain, Oldboy. KPop Idols. Hong Kong: Hong Kong University Press.

[19]. Taylor-Jones, Kate E. 2013. Rising Sun, Divided Land: Japanese and South Korean Filmmakers. London: Wallflower Press.

[20]. The Crucible, Directed by Hwang Dong-hyuk. 2011. Hong Kong: CN Entertainment Ltd, 2011. DVD.

[21]. Wollstonecraft, Mary. 1792. A vindication of the rights of woman: with strictures on political and moral subjects. Boston: Thomas and Andrews.

\title{
Nam giới Hàn Quốc trong liên hoan phim phương Tây: Những hình ảnh nam tính trong năm phim đạt giải thưởng ở Nam Hàn
}

\author{
Gabriel F. Y. Tsang \\ Đại học Sun Yat-sen \\ Tác giả liên hệ: tsangfanyu@hotmail.com
}

Ngày nhận bản thảo: 10-01-2018; ngày chấp nhận đăng: 01-05-2018; ngày đăng: 30-9-2018

Tóm tắt-Nam tính là một vấn đề trừu tượng và phụ thuộc một thứ gì đó được xem là đại diện. Nó gồm cả cá nhân và tập thể, trong sự tương tác với những động lực lịch sử và văn hóa. Bài viết này tập trung vào những hình ảnh nam tính Hàn Quốc trong năm bộ phim Hàn Quốc đã giành giải thưởng. Từ cả hai góc nhìn lịch đại và quốc tế, nam tính lý tưởng, thực tế và nam tính trong phim ảnh được phân biệt rất rõ, trong đó cho rằng nam tính Hàn Quốc cổ đại và hiện đại không hoàn toàn gắn bó với một hệ tư tưởng được chia sẻ, kỳ vọng cố định nào. Có những biến động trong sự hồi đáp đối với chủ ý con người, tính chất là một dân tộc và toàn cầu hóa văn hóa. Lập luận chính của bài viết này là, quy định thông thường không phải là nguồn duy nhất ảnh hưởng đến hình ảnh đại diện của nam tính. Bởi thậm chí sự chống đối con người lý tưởng cũng có thể mang đến cảm thức nam tính. Mở rộng luận điểm này để quan tâm đến tiếp thị phim quốc tế, bài viết này cũng đặt ra câu hỏi rằng liệu việc đa dạng hóa các tính năng giới có làm mờ đi sự nam tính của Hàn Quốc và tạo ra sự nhận dạng giới tính mới.

Từ khóa-toàn cầu hóa văn hóa, nam tính, tính chất là một quốc gia, phim Hàn Quốc. 